\title{
Curbing Youth Restiveness and Conflicts Through Effectual Structural Policies for Rural Employment Generation in Nigeria
}

\author{
$\begin{array}{lll}\text { C.C. } \text { Ezeh }^{1} \quad \text { O.H. Ezeh } & \text { C.O. Otuagbo } \\ & 1\end{array}$ \\ 1.College of Agriculture \\ 2.Department of Community Medicine \\ Ahmadu Bello University, Zaria. Nigeria
}

\begin{abstract}
The apparent neglect of Nigeria's rural sector has provoked daunting challenges including youth restiveness, ethno-religious conflicts, unemployment and pervasive poverty. It is logical to finger rural unemployment as the antecessor of those other consequences. While it has been argued that the rate of unemployment is higher in urban than rural Nigeria, the nature and magnitude of rural unemployment (mostly underemployment) is becoming worrisome. For instance, youth unemployment in the country averaged 23.63 percent from 2014 until 2018 reaching an all-time high of 38 percent in Q2 of 2018 and a record low of 11.70 percent in Q4 of 2014. Furthermore, the Labour Statistics Report of Nigeria in Q4 of 2017 showed that there are about 7.9 million Nigerian youths aged $15-34$ that are unemployed, mostly in the rural areas. Thus paper makes an introspection into what went wrong and explores vistas through effectual structural policies on rural infrastructures, agricultural transformation, skills acquisition, robust and sustainable credit and so on. These policies are aimed at realizing the multi-pronged goals of curbing youth restiveness, checking rural - urban migration, generating income and employment and transforming the agricultural sector for meaningful contribution to the country's GDP. The need is imperative and there is no better time for these policies than now.
\end{abstract}

Keywords: Youth restiveness policies rural employment generation

DOI: $10.7176 / \mathrm{JESD} / 10-16-20$

Publication date: August $31^{\text {st }} 2019$

\section{Introduction}

Perhaps, besides the fledgling economy emerging from the throes of the recent recession, the unemployment rate in Nigeria at present poses a major threat to national stability. Needless emphasizing the nexus between the downturn in the economy and the spiraling unemployment rate. According to Anaeto (2016), as the economic downturn persisted, the number of unemployed and underemployed persons in Nigeria surged to 22.4 million in the fourth quarter of 2015. Corroborating, the National Bureau of statistics (NBS, 2016) reported that the Nigerian unemployment rate was 13.3 percent in Q2 of 2016 up from 12.1 percent in Q4 of 2015. Unfortunately, the trend rather than abating, has continued to rise. The unemployment rate in the country rose to 23.10 percent in Q3 of 2018 up from 22.70 percent in Q2 of 2018 (NBS, 2019). Unemployment rate in Nigeria averaged 12.31 percent from 2006 to 2018 reaching an all-time high of 23.10 percent in 2018 and a record low of 5.10 percent in 2010.

The unemployment situation in Nigeria, dire as it is, becomes more worrisome when it relates to youth unemployment. Youth unemployment in the country averaged 23.63 percent form 2014 until 2018 reaching an alltime high of 38 percent in Q2 of 2018 and a record low of 11.70 percent in Q4 of 2014 (NBS, 2019). Analysis of youth unemployment by geographic / settlement locations indicates that youth unemployment is mostly in rural areas and rapidly growing; the numbers rose form 2.9 million in 2008 to about 5.9 million in 2012 (Akande, 2014). Furthermore, the Labour Statistics Report of Nigeria in Q4 of 2017 showed that there are about 7.9 million Nigerian youths aged $15-34$ that are unemployed, mostly in the locations indicates that youth unemployment is mostly in rural areas and rapidly growing; the numbers rose from 2.9 million in 2008 to about 5.9 million 2012 (Akande, 2014). Furthermore, the Labor Statics Report of Nigeria in Q4 2017 showed that there are 7.9 million Nigeria youth aged $15-34$ that are unemployed, mostly in the rural areas (NBS, 2018).

Table 1: Unemployment Indices in Nigeria

\begin{tabular}{llllll}
\hline Index & Current & Previous & Highest & Lowest & Unit \\
\hline Population & 190.89 & 185.99 & 190.89 & 45.14 & Millions $[+]$ \\
Unemployment & 23.10 & 22.70 & 23.10 & 5.10 & Percent $[+]$ \\
Youth unemployment & 38.0 & 36.50 & 38.0 & 11.20 & Percent $[+]$ \\
\hline
\end{tabular}

Source: Trading-Economics (2018); NBS (2019).

Youth unemployment has serious social, economic and political consequences; the link between youth unemployment and social eruptions including conflicts, crime and insecurity is intuitive (Adegoke, 2015). According to the Bureau for Public Services Reform (BPSR, 2017), youth unemployment compounds the security and socio-political challenges currently faced by the Nigerian state including the insurgency in the North-East, an active secessionist movement in the South - East, periodic irruptions of militancy in the Niger Delta and other serious crimes in other parts of the country. 


\section{Conceptual Framework}

Unemployment describes the population or persons aged $15-64$ who during the reference period were available for work, actively seeking for work, but were unable to find work (ILO, 2011). The Nigerian National Bureau of Statistics like most countries in the world uses a variant of the ILO definition such that the unemployed is the proportion of those in the labour force (not in the entire economic active population, nor the entire Nigerian population) who were actively looking for work but could not find work for at least 20 hours during the reference period to the total currently active (labour force) population (NBS, 2016).

Economists may want to categorize unemployment into voluntary and involuntary unemployment. Furthermore, unemployment, voluntary or involuntary, may be broken down into three types - frictional, cyclical and structural and, with respect to rural agricultural settings, a fourth type-seasonal unemployment may be classified (Abalu, 1988; Economics Help, 2010; Iwayemi, 2013).

Unemployment is often used as a measure of the health of an economy (Iwayemi, 2013). The most frequently used measure of unemployment is the unemployment rate, which is the number of unemployed people divided by the number of people in the labour force (BLS, 2015).

A corollary of unemployment is under- employment, also referred to as disguised unemployment. This is a preponderant feature of unemployment in Nigeria and obtains in both rural and urban sectors. NBS (2016) described under-employment as when a person works less than full time which is 40 hours in a week but works at least 20 hours on the average a week and / or work full time but engaged in an activity that underutilized ones skills, time and educational qualifications. According to World Bank Report (2014) on Nigeria, the country's employment challenges are more of underemployment rather than unemployment. The report further posited that most Nigerians cannot afford not to work but a large share of the population engage in low productivity and low paying tasks. Corroborating, other scholars have argued that the problem in SSA is not unemployment but rather underemployment as many young people are engaged in insecure jobs with meager pay (World Bank, 2009; Altman, 2013).

Youth unemployment in Nigeria is not a recent phenomenon. According to Alanana (2013), the rate of youth unemployment has been high even during the period of economic normalcy, that is the oil boom era $1970 \mathrm{~s}(6.3 \%)$, $1980 \mathrm{~s}(9.8 \%)$ and the $1990 \mathrm{~s}(11.5 \%)$. Based on age group classification, Iwayemi (2013) stated that the $15-24$ age group has the highest unemployment rate of 37.7 percent followed by the $25-44$ age group with unemployment of 24.4 percent.

\section{Precursors of Rural Unemployment}

Literature is replete with information on the possible causes of rural unemployment. Brief mention will be made here of the notable causes of rural unemployment which include:

a. Poor infrastructure: the dearth of basic infrastructure in most rural communities of the country profoundly mitigates the effective mobilization and utilization of human and natural resources in these areas. Undoubtedly, this is the major cause of rural-urban migration among Nigerian youths. Infrastructures like roads potable water, electricity, health services, credit and a viable farm input delivery system are required for the sector to contribute meaningfully to GDP by having the citizens productively engaged.

b. Lack of skills - most of the youths in the rural areas are not only uneducated but generally lack the skills required to engage in viable productive ventures. According to Iwayemi (2013) this factor perpetuates underemployment. Since people have to make do with any paying jobs for sustenance. Schools in rural areas are generally more deficient in infrastructures, teaching facilities and teacher quality than schools in urban areas. This results in skills gap which is further compounded by high school dropouts in rural areas (Akande, 2014; Altman et al, 2013).

c. Neglect of the agricultural sector: Rural Nigeria is essentially agricultural; majority of the residents being farmers. The apparent neglect of the agricultural sector following the discovery of oil has left the sector in shambles, unproductive and unattractive (Ezeh, 2012). The result is that productivity is low and in many communities, only the aged are left to eke out a living from their subsistence activities.

d. Weak educational background: A corollary of the factors earlier mentioned as concomitant to poor skills acquisition is the weak educational background of many rural youths. Even those who have gone through primary and secondary education do not seem to be adequately equipped for employment. As Altman et al (2013) put it, a skill gap driven by early school dropouts, weak quality of education and a relative lack of core competencies that are critical for employment including ICT are focal issues of concern.

e. Poor labour ethics: Poor attitude to work by youths and even staff that service the few government agencies in the communities (e.g. extension agents, health workers) has mitigating effects. This on the one hand, and the lure of city life fired by the get-rich-quick syndrome on the other, adversely contrast with the sterling virtues of hard work and diligence. 
f. Poor credit facilities: Youth unemployment, underemployment and poverty are some of repercussions of the non-existence and/or inaccessibility of credit facilities in the rural areas. Consequently, there exists a gaping financial deficit and no meaningful investments can be made, perpetuating unemployment and a viscous circle of poverty.

g. Faulty programme designs and implementation - It would appear that the faulty development planning strategies of the 1970s, 1980s and 1990s had aggravated the unemployment situation in rural Nigeria. The emphasis was on industrialization, and even the programmes that were rural based as DFRII, ADPs, RBDAs etc, did not make the desired impact in spite of the huge sums budgeted for them. Invariably, they were 'top down' oriented rather than 'bottom up' (Ezeh, 1993).

Besides the above specific precursors of rural youth unemployment, a number of other factors including corruption, profligacy, capital-intensive as opposed to labour-intensive technologies, influx of aliens into the labor market have, in one way or the other, contributed to the growing incidence of rural unemployment $n$ Nigeria (Ezeh, 1993; Ewumi, 2014).

\section{Structural policy thrusts: The way forward}

The challenges in setting the agenda for sustainable rural employment generation in Nigeria are multidimensional. They encompass social, economic, political and cultural issues and require multi-pronged attention aimed at creating farm and non-farm employment opportunities. Major policy thrusts advocated in this treatise include:

\section{Provision of infrastructures}

The provision of rural infrastructures like roads, portable water, electricity, credit, marketing, health and internet facilities is key to a sustainable rural employment generation. An effectual policy aimed at massively developing rural infrastructures will go a long way in generating and sustaining employment among rural youths.

\section{Promoting sustainable agricultural transformation}

The current emphasis on diversifying the economy leveraging on the limitless potentials existing in the agricultural sector is germane. The current effort at attaining self-sufficiency in rice production so as to reduce the huge import bill on the staple is laudable and is yielding positive results in the area of employment generation. Complementing the provision of rural infrastructures, the opening up of the agricultural sector will achieve the multi-pronged objectives of increasing rural incomes, generating employment and checking rural - urban migration. Focal areas of action will include the provision of improved technologies, strengthening extension delivery accessible and affordable credit and encouraging cooperative groupings.

3. Enhancing skills acquisition

A policy framework to provide and sustain facilities for skills acquisition at grassroots levels will definitely foster the engagement of rural youths in productive ventures. Areas of actions under this scheme are diverse from the processing of farm products, handicrafts, to light manufacturing. No doubt, acquisition of vocational skill would reduce both unemployment and underemployment, promote entrepreneurships and start-ups in micro-businesses.

\section{Robust and sustainable credit}

The resource capacity of a typical rural farmer is characteristic; cash flow is low as most output from stallholder enterprises are consumed by family. Consequently, ability for cash transactions is weak, thus perpetuating the viscous circle of poverty (Nwagbo and Ezeh, 1990). A robust and sustainable rural credit policy becomes imperative to provide the necessary funds for both farm and non-farm investments, including small and medium scale enterprises (SMEs). The current interventions by the Central Bank of Nigeria (CBN) in this regard is most welcome. For most impact, primary financial institutions need to be strengthened and supervised.

\section{Poverty Reduction Programmes}

The significance of rural poverty is underscored by the fact that it accounts for nearly 63 percent of poverty worldwide and between 65 and 90 percent in sub-saharan Africa (SSA), where Nigeria is situated (Etim and Edet, 2007). Policies and programmes on poverty reduction need to be re-examined and galvanized for both effectiveness and reach. Such policies and programmes must operate in tandem with those for agricultural transformation, skills acquisition and credit provisions. Action areas in this regard will involve scaling up interventions government agencies, parastatals and non- governmental organizations (NGOs). The role of NGOs in poverty reduction cannot be over emphasized. Suharko (2007) would argue that, compared to government, NGOs have comparative advantage in reaching target groups at the grassroots.

\section{Empowering rural women}

Subsumed in the overall goal of poverty reduction is the special need of rural female folks who constitute about 50 percent of the rural population (NPC, 2006). They attend to over 70 percent of both on-farm and 
off-farm activities in the rural sector and yet control less than 15 percent of the proceeds; a situation that is said to be responsible for the economic alienation and social marginalization of rural women. As Moharty (2007) succinctly put it, women are at the receiving end, holding the shorter end of the stick. Policy interventions are necessary to guarantee empowerment, self-reliance and employment through;

- The promotion of equitable access to agricultural inputs and services, in particular credit.

- Policy support of women organizations e.g. cooperatives and self - help groups (SHGs)

- The elimination of discriminatory legislation in the ownership and control of productive resources, e.g. land.

- Funding and directing of more research on the contribution of rural women to agricultural and rural development (Ezeh and Ezeh, 2003).

\section{Conclusion}

Youth employment generation and poverty reduction in rural Nigeria are key issues of development considering the very precarious living conditions of most rural dwellers. These objectives, insurmountable as they may seem, are realizable through effectual policy thrusts as enunciated above. It must be emphasized that a synergy of focal action areas by all stakeholders is sine qua non to achieving the multi-pronged goals of curbing youth restiveness and conflicts, checking rural - urban migration, generating incomes and employment, stepping up livelihoods and transforming the agricultural sector for more meaningful contribution to the country's GDP. Leveraging on the impetus of the present administration to fix the 'mission links' responsible for the dislocations being experienced in the rural sector, there is no better time for action than now.

\section{References}

Abalu, G.O.I (1988). Rural employment generation in Nigeria: First things first. Presidential address at the Annual Conference of Nigerian Association of Agric. Economists, OAU, Ile - Ife.

Adegoke, N. (2015). Youth unemployment and security challenges in Nigeria. Asian Journal of Humanities and Social Studies 3(1): $19-28$.

Akande, A. (2014). Youth unemployment in Nigeria: A situation analysis. Paper presented in collaboration with Brookings African Growth Initiative; September, 23 pp. 21.

Alanana, O.O. (2013). Youth Unemployment in Nigeria: Some implications for the third millennium. Global Journal of Social Sciences, 2(1): $21-26$.

Bureau of Labour Statistics (BLS, 2015). Who is considered as unemployed. BLS, Washington, D.C. Retrieved at www.blsd.gov/cps...html

Bureau for Public Service Reform (BPSR, 2017). Tackling Youth Unemployment in Nigeria: a Policy Note, Abuja, Nigeria.

Economics Help (2015). Definition of unemployment. Retrieved at www.economicshelp.org $>$ home $>$...economicshelpblog $>$.

Etim, N.A. and Edet, G.F. (2007). Determinants of Poverty among peri-urban households in Uyo, Nigeria. Nig. J. of Agric. Food and Environment, 5(2): 39 - 51.

Ewumi, E. (2014). Factors responsible for the high rate of unemployment in Nigeria. Presentation at the Jarushub Careers Management Entrepreneurship workshop, March 25. Retrieved at: www:jarushub.com/factorsresponsible....html

Ezeh, C.C. (1993). Modal issues in generating sustainable rural employment in Nigeria: Potentials and policy linkages. Proceedings of the 1993 workshop of the society for international Development (SID), Zaria Chapter P. 59.

Ezeh, C.C. and Ezeh, O.H. (2003). Economic Empowerment of Nigerian rural women through enhanced participation in the agricultural sector. J. for Voc and Tech. Edu. 4(2):26 - 33.

Ezeh, C.C. (2012). Training of middle level agricultural extension manpower and the challenges of a changing clientele in Nigeria. J. of Voc. Studies. 6(1): 192 - 197.

International Labor Organisation (ILO, 2011). Global empowerment trend: The challenges of a job recovery. ILO, Geneva. Retrieved at www:ilo.gov/global..challenges<-sco/

Iwayemi, A. (2013). Youth unemployment in Nigeria: Challenges and way forward. Presentation of the Evaluative Group, World Bank (IBRD) July, 23 - 24.

Moharty, M. (2007). Microcredit, NGOs and poverty alleviation The Hindu, November, 15.

National Bureau of Statistics (NBSM, 2016). Unemployment Watch Report, August, 2016. Abuja, Nigeria.

National bureau of Statistics (NBS, 2019). Fourth Quarter 2018 Unemployment Report, Abuja, Nigeria.

National Population Commission (NPC, 2006). National Population and Household Survey National Population Commission, Abuja, Nigeria.

Nwagbo, E.C. and Ezeh, C.C. (1990). Agricultural inputs delivery system for small scale farmers: The Case of Finance. Samaru J. Agric. Edu 4(1and2): 44- 52. 
Suharko, Y. (2007). The role of NGOs in rural poverty reduction: The case of India and Indonesia Discussion Paper No 160, GSID, Nagoya University.

Trading Economics (2018). Nigeria Youth unemployment rate. Retrieved at https://tradingeconomics.com.>nigeria $>$...pdf.

World Bank (2009). Youth and Employment in Africa. World Bank Group, Washington DC.

World Bank (2014). Youth Employment in Sub-Saharan Africa. World Bank Documents, World Bank Group. Washington, DC. 